\title{
Scale-Up Information for Gas-Phase Ammonia Treatment of Uranium in the Vadose Zone at the Hanford Site Central Plateau
}

\author{
MJ Truex \\ JE Szecsody \\ L Zhong \\ JN Thomle \\ TC Johnson
}

September 2014

Pacific Northwest

NATIONAL LABORATORY

Proudly Operated by Battelle Since 1965 


\title{
DISCLAIMER
}

This report was prepared as an account of work sponsored by an agency of the United States Government. Neither the United States Government nor any agency thereof, nor Battelle Memorial Institute, nor any of their employees, makes any warranty, express or implied, or assumes any legal liability or responsibility for the accuracy, completeness, or usefulness of any information, apparatus, product, or process disclosed, or represents that its use would not infringe privately owned rights. Reference herein to any specific commercial product, process, or service by trade name, trademark, manufacturer, or otherwise does not necessarily constitute or imply its endorsement, recommendation, or favoring by the United States Government or any agency thereof, or Battelle Memorial Institute. The views and opinions of authors expressed herein do not necessarily state or reflect those of the United States Government or any agency thereof.

\author{
PACIFIC NORTHWEST NATIONAL LABORATORY \\ operated by \\ BATTELLE \\ for the \\ UNITED STATES DEPARTMENT OF ENERGY \\ under Contract DE-AC05-76RL01830
}

Printed in the United States of America
Available to DOE and DOE contractors from the Office of Scientific and Technical Information, P.O. Box 62, Oak Ridge, TN 37831-0062; ph: (865) 576-8401 fax: $(865) 576-5728$
email: reports $a$ adonis.osti.gov
Available to the public from the National Technical Information Service 5301 Shawnee Rd., Alexandria, VA 22312 ph: (800) 553-NTIS (6847) email: orders@ntis.gov <http://www.ntis.gov/about/form.aspx> Online ordering: http://www.ntis.gov




\title{
Scale-Up Information for Gas-Phase Ammonia Treatment of Uranium in the Vadose Zone at the Hanford Site Central Plateau
}

\author{
MJ Truex \\ JE Szecsody \\ L Zhong \\ JN Thomle \\ TC Johnson
}

September 2014

Prepared for

the U.S. Department of Energy

under Contract DE-AC05-76RL01830

Pacific Northwest National Laboratory

Richland, Washington 99352 



\section{Summary}

Uranium is present in the vadose zone at the Hanford Central Plateau and is of concern for protection of groundwater. The Deep Vadose Zone Treatability Test Plan for the Hanford Central Plateau identified gas-phase treatment and geochemical manipulation as potentially effective treatment approaches for uranium and technetium in the Hanford Central Plateau vadose zone. Based on laboratory evaluation, use of ammonia vapor was selected as the most promising uranium treatment candidate for further development and field testing. While laboratory tests have shown that ammonia treatment effectively reduces the mobility of uranium, additional information is needed to enable deployment of this technology for remediation. Of importance for field applications are aspects of the technology associated with effective distribution of ammonia to a targeted treatment zone, understanding the fate of injected ammonia and its impact on subsurface conditions, and identifying effective monitoring approaches. In addition, information is needed to select equipment and operational parameters for a field design.

As part of development efforts for the ammonia technology for remediation of vadose zone uranium contamination, field scale-up issues were identified and have been addressed through a series of laboratory and modeling efforts. This report presents a conceptual description for field application of the ammonia treatment process, engineering calculations to support treatment design, ammonia transport information, field application monitoring approaches, and a discussion of processes affecting the fate of ammonia in the subsurface. The report compiles this information from previous publications and from recent research and development activities. The intent of this report is to provide technical information about these scale-up elements to support the design and operation of a field test for the ammonia treatment technology. 


\section{Acknowledgments}

This document was prepared by the Deep Vadose Zone-Applied Field Research Initiative at Pacific Northwest National Laboratory. Funding for this work was provided by the U.S. Department of Energy (DOE) Richland Operations Office. The Pacific Northwest National Laboratory is operated by Battelle Memorial Institute for the DOE under Contract DE-AC05-76RL01830. 


\section{Acronyms and Abbreviations}

$\begin{array}{ll}\mathrm{cm} / \mathrm{min} & \text { centimeter(s) per minute } \\ \text { Eh } & \text { oxidation-reduction potential } \\ \text { ERT } & \text { electrical resistivity tomography } \\ \mathrm{h} & \text { hour(s) } \\ \text { in. } & \text { inch(es) } \\ \mathrm{M} & \text { moles per liter } \\ \mathrm{mL} / \mathrm{min} & \text { milliliter(s) per minute } \\ \mathrm{mm} & \text { millimeter(s) } \\ \mathrm{pCi} / \mathrm{g} & \text { picocurie(s) per gram } \\ \mathrm{PNNL} & \text { Pacific Northwest National Laboratory } \\ \mathrm{QA} & \text { quality assurance } \\ \mu \mathrm{S} / \mathrm{cm} & \text { microsiemens per centimeter } \\ \mathrm{wt} \% & \text { weight percent }\end{array}$





\section{Contents}

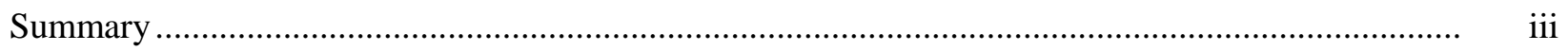

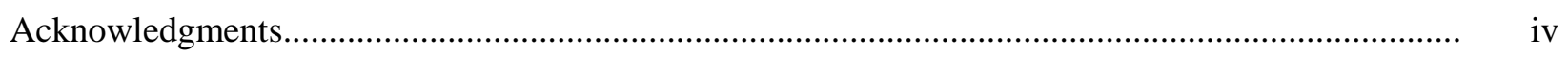

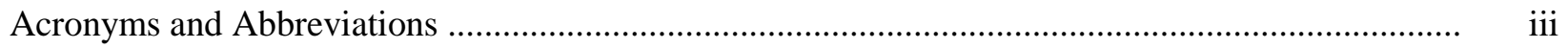

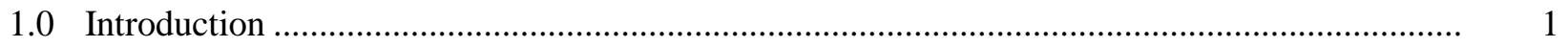

2.0 Conceptual Field Application .............................................................................. 2

3.0 Ammonia Treatment Design Calculations........................................................................... 5

4.0 Ammonia Transport in the Subsurface …........................................................................ 7

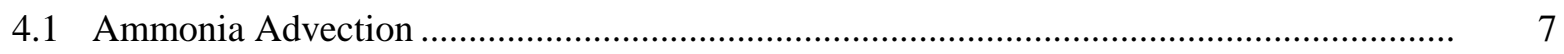

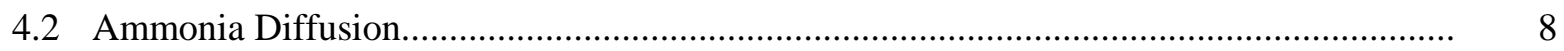

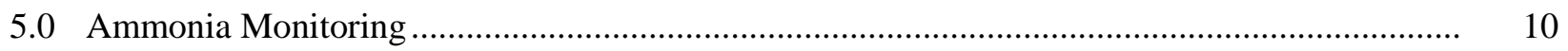

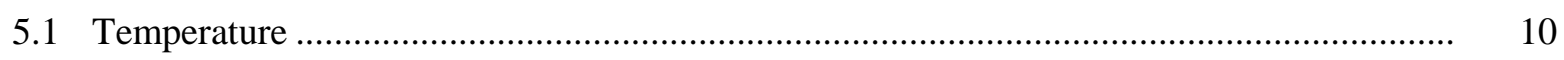

5.2 Bulk and Pore-Water Electrical Conductivity ............................................................ 11

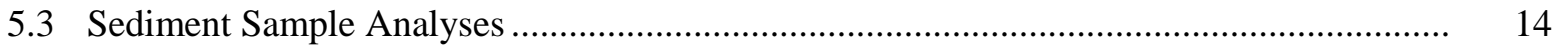

5.4 Sediment Laboratory Treatment Evaluation ................................................................ 15

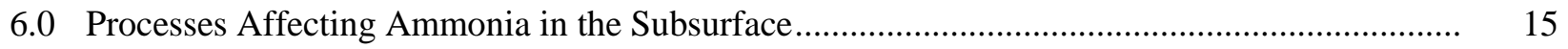

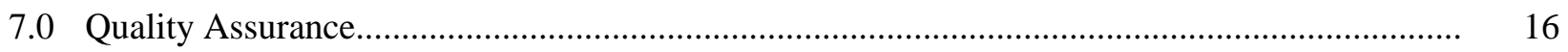

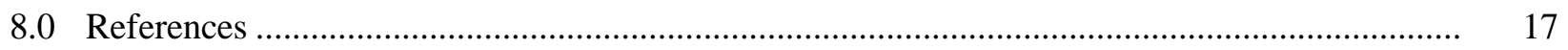




\section{Figures}

1. Overview of the processes that occur with injection of ammonia vapor into an unsaturated uranium-contaminated Hanford sediment.

2. Conceptual depiction of ammonia distribution in the subsurface from an injection well.

3. Conceptual field layout cross section.

4. Results of soil-column leaching studies for ammonia-treated sediments and different types of post-treatment exposure gas and time 6 weeks to 3 years prior to leaching with groundwater.

5. Resulting $\mathrm{pH}$ profile for $\mathrm{NH}_{3}$ gas injection into 610 -cm-long $(20-\mathrm{ft})$ columns at different gas flow rates and associated ammonia velocities within the columns

6. Plan view of heterogeneous sediment packing for 2D diffusion studies with a central high-permeability layer and a side high-permeability layer

7. Ammonia pore-water concentration distribution in heterogeneous systems with a central high-permeability layer and a side high-permeability layer

8. Observed temperature response in a 1D soil column with injection of $100 \%$ ammonia gas...................

9. Sediment pore-water cation concentration over time during $10 \%$ ammonia gas treatment (Hanford Formation sediment)

10. Changes in pore-water ion concentrations, pore-water specific conductivity, and bulk conductivity over time after ammonia treatment

\section{Tables}

1. Sequential extraction of uranium from sediment samples 


\subsection{Introduction}

The Deep Vadose Zone Treatability Test Plan for the Hanford Central Plateau (DOE/RL 2008) identified gas-phase treatment and geochemical manipulation as potentially effective treatment approaches for uranium and technetium in the Hanford Central Plateau vadose zone. Delivery of aqueous-phase amendments to the vadose zone can be problematic (e.g., Zhong et al. 2009), whereas use of gas-phase delivery may be advantageous (Denham et al. 2007; Dresel et al. 2011). Thus, investigations have focused on candidates using gas-phase amendments, water mist, or foam delivery mechanisms. Gas-phase geochemical manipulation was initially studied as a potential treatment to address uranium contamination in the vadose zone (Szecsody et al. 2010a). Candidate techniques included geochemical reduction, $\mathrm{pH}$ change (acidic and alkaline), and additions of chemicals (phosphate and ferric iron) to form specific precipitates. Reactants were advected into one-dimensional (1D) columns packed with uraniumcontaminated sediment from the 200 Area of the Hanford Site as a reactive gas (for $\mathrm{CO}_{2}, \mathrm{NH}_{3}, \mathrm{H}_{2} \mathrm{~S}$, and $\mathrm{SO}_{2}$ ), with a $0.1 \%$ water content mist (for $\mathrm{NaOH}, \mathrm{Fe}(\mathrm{III}), \mathrm{HCl}$, and $\mathrm{PO}_{4}$ ) and with a $1 \%$ water content foam (for $\mathrm{PO}_{4}$ ). The study examined the effectiveness of each candidate individually. Use of ammonia vapor was selected as the most promising uranium treatment candidate for further development and field testing.

Additional development of ammonia treatment for uranium has been conducted to improve understanding of the process and prepare for planned field testing (Szecsody et al. 2010a, b, 2012). Figure 1 depicts the three primary elements of uranium treatment by ammonia vapor. When a gas containing ammonia vapor is injected into an unsaturated porous medium, a large percentage of the ammonia partitions into the pore water due to ammonia's low Henry's Law constant (a dimensionless value of about $6.5 \times 10^{-4}$ ) of ammonia (Step 1, Figure 1). For example, a $5 \%$ by volume ammonia vapor produces an equilibrium pore-water concentration of about $3 \mathrm{M}$ ammonia. Through dissociation, this ammonia concentration results in the pore water, starting at around $\mathrm{pH} 8$, rising to about $\mathrm{pH} 11.5$ (Szecsody et al. 2010a, b, 2012). Ion exchange and mineral dissolution (including silicate dissolution) is caused by the caustic pH (Step 2, Figure 1) (Szecsody et al. 2010a, b, 2012). With high total dissolved solids, precipitates start to form, especially as the $\mathrm{pH}$ is buffered back toward neutral. The precipitates may incorporate uranium (e.g., sodium boltwoodite) or may be compounds such as quartz, chrysotile, calcite, diaspore, and hematite that could coat uranium already precipitated or adsorbed on the sediment surface (Step 3, Figure 1) (Szecsody et al. 2010a, b, 2012). The goal of the dissolution and reprecipitation process is to create uranium precipitates or coatings that render uranium less mobile than before treatment. 


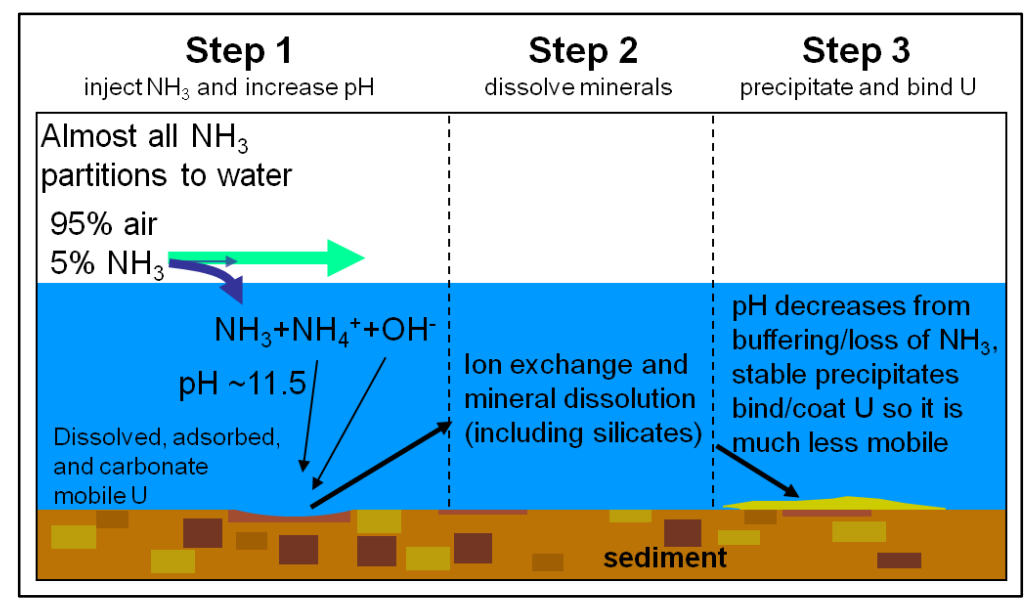

Figure 1. Overview of the processes that occur with injection of ammonia vapor into an unsaturated uranium-contaminated Hanford sediment.

As part of development efforts for the ammonia technology, scale-up issues were identified and have been addressed through a series of laboratory and modeling efforts. The ensuing sections of this report present a conceptual description for field application of the ammonia treatment process, engineering calculations to support treatment design, ammonia transport information, field application monitoring approaches, and a discussion of processes affecting the fate of ammonia in the subsurface. The report compiles this information from previous publications and from recent research and development activities.

\subsection{Conceptual Field Application}

Field implementation of the ammonia technology involves injection of ammonia gas mixed with air into a subsurface target zone. The ammonia partitions into the pore water, which approaches the equilibrium partitioning concentration defined by the gas-phase ammonia concentration and the Henry's Law constant (discussed in more detail in Section 3.0). Because partitioning is very rapid and the Henry's Law constant is low, a sharp dissolution front is expected with near-equilibrium ammonia gas and liquid concentrations behind the front and low concentrations elsewhere (Figure 2). Ammonia treatment results in uranium surface phases being coated with or incorporated into aluminosilicate precipitates. In this process, uranium is not chemically reduced, so the oxidation state does not affect treatment effectiveness and the sequestration process is not readily reversible in an oxic vadose zone. Under post-treatment neutral $\mathrm{pH}$ conditions, precipitates formed during ammonia treatment have low solubility and would dissolve slowly over long time periods as part of natural weathering processes. Transport of uranium that is bound or coated by precipitates will be limited, thereby reducing the flux of uranium to the groundwater. 


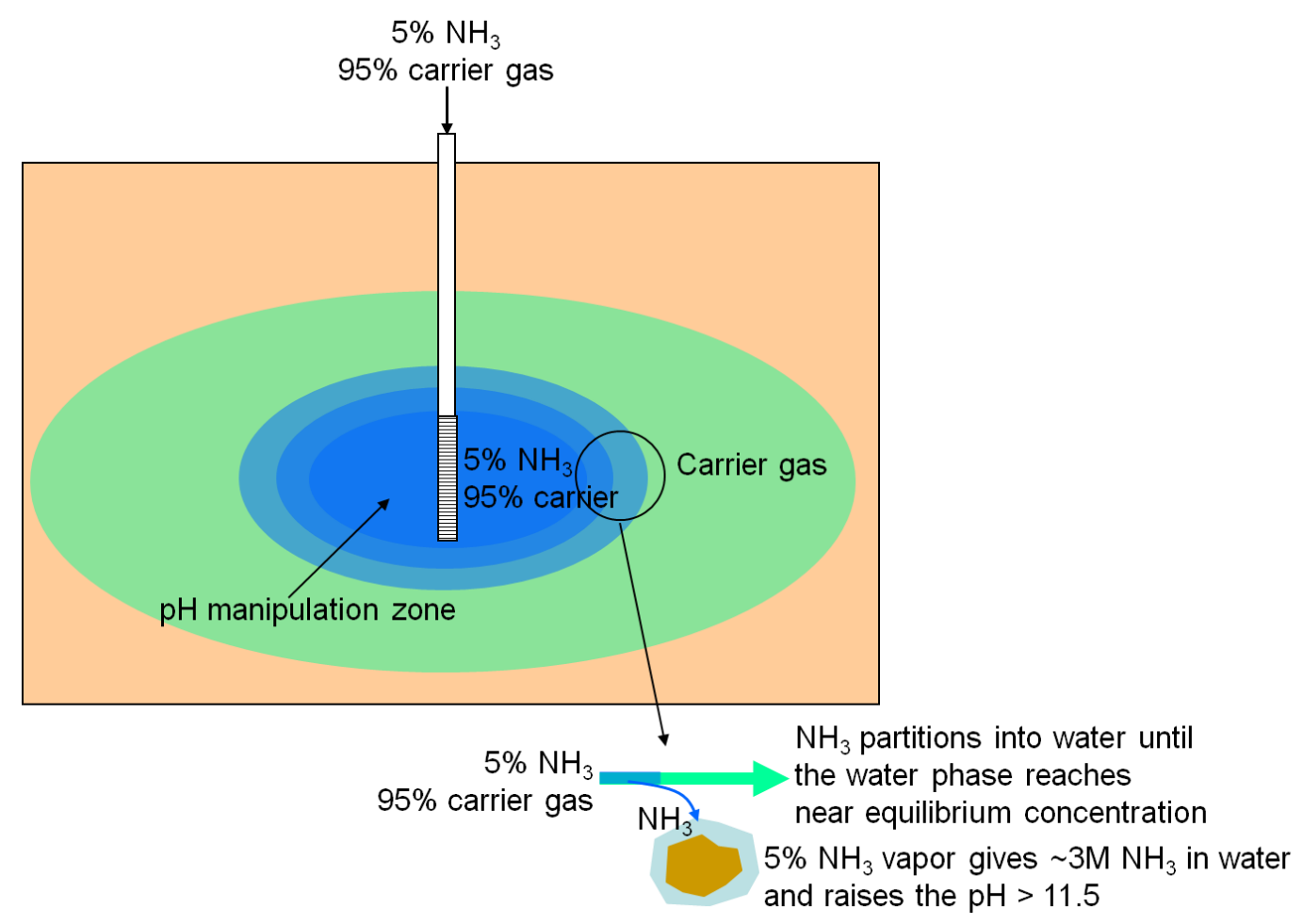

Figure 2. Conceptual depiction of ammonia distribution in the subsurface from an injection well.

During the ammonia treatment process, the increase in pore-water $\mathrm{pH}$ releases ions into solution where they will be in a mobile state until the $\mathrm{pH}$ decreases toward neutral, causing precipitation reactions. Under most vadose zone conditions, movement of pore water is very slow and a decrease in $\mathrm{pH}$ will occur before any significant movement takes place. In other words, the reaction processes are rapid compared to contaminant transport. Although this mobilization is temporary, the duration of $\mathrm{pH}$ return to neutral needs to be considered when assessing potential applications of the technology.

Installation and implementation of the ammonia treatment process is expected to include the following elements. This approach takes into consideration characterization and monitoring needed to address sitespecific conditions with respect to selecting gas injection depth interval targets and evaluating actual injected gas distribution and the associated zone of effective treatment.

Characterization of the site is needed to support of the treatment design. Geophysical logging (neutron moisture and spectral gamma logging) and characterization of sediment from initial borehole(s) installed at the site are needed for site-specific field design. Geophysical data provide a vertical profile of contamination for use in selecting an appropriate target depth interval(s) for gas injection. Sequential extraction analysis of sediment samples from the target interval(s) augment these geophysical data with uranium concentration data and an estimate of the relative amount of mobile uranium present. Sediment sample analysis should also include evaluation of pore-water chemistry and ammonia treatment of the sediments in the laboratory to estimate site-specific treatment effectiveness. The laboratory data will quantify the increase in $\mathrm{pH}$ due to the ammonia exposure and the timescale of $\mathrm{pH}$ decrease and associated precipitation/sequestration processes following initial ammonia distribution. This information can then be used to guide the field design and monitoring approach. The laboratory tests could also include 
sediment chemistry and leaching studies in the laboratory to evaluate the long-term stability of sequestered uranium.

The field installation includes the injection well and a multi-level monitoring network to evaluate three-dimensional (3D) tracer gas flow and ammonia distribution in the targeted treatment zone (Figure 3). Baseline monitoring should provide a vertical distribution of temperature and electrical resistivity electrodes at strategic lateral and vertical locations around the injection well screen location. Electrical resistance tomography can be applied to provide $3 \mathrm{D}$ information about the ammonia distribution based on the increase in pore-water conductivity that results from the dissolution reactions induced by ammonia treatment. Surface electrodes may also be useful depending on the depth of the treatment zone. Temperature is also expected to rise due to ammonia dissolution. The monitoring network should also include gas-sampling locations so that, at minimum, a pre-ammonia gas tracer test can be conducted. These locations can also provide supporting information about ammonia distribution during the treatment. In addition to subsurface infrastructure, a surface cover is needed to preclude injected gas "short-circuits" to the surface. Aboveground equipment that can regulate gas injection to a specified rate is needed, as is down-hole installation of a packer or other sealing device to force gas to exit via the well screen.

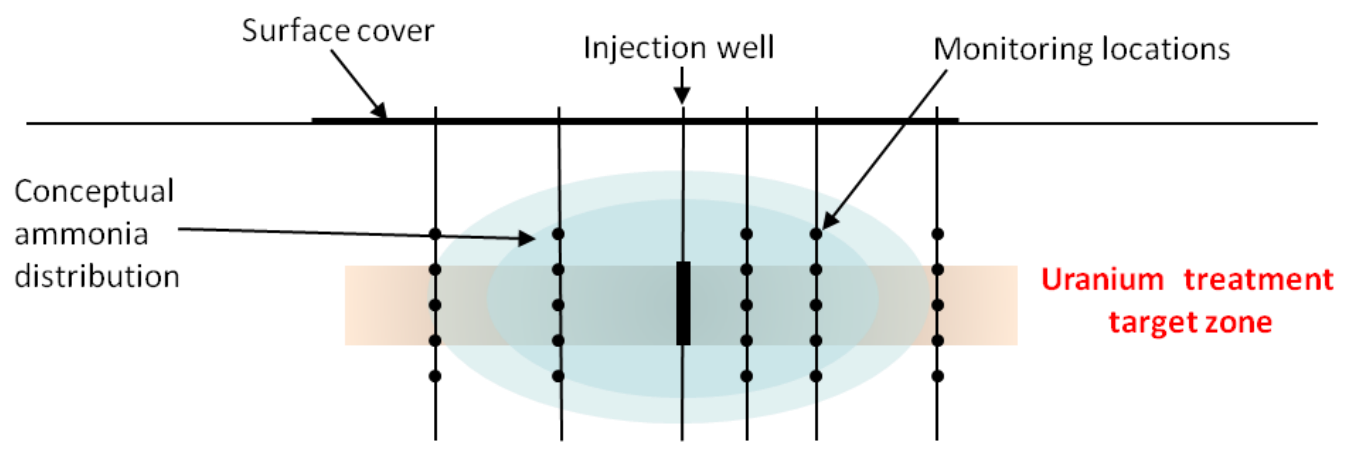

Figure 3. Conceptual field layout cross section.

Pre-injection efforts may need to include permeability testing and tracer gas injection testing to provide baseline information about injected gas flow in the treatment zone. The amount of ammonia needed to achieve the desired conditions in the targeted treatment zone can be estimated based on calculations in Section 3.0. Ammonia injection would likely occur over a period of days to a few weeks for most applications. Monitoring during operations for temperature, electrical resistivity tomography (ERT), and potentially ammonia concentrations at selected gas-sampling ports would be used to determine when the ammonia distribution is sufficient for the target treatment zone. An incubation period would be needed to allow uranium sequestration reactions to occur prior to any post-treatment sampling. Information from pre-treatment laboratory tests and from the ERT data can be used to indicate when posttreatment sampling to verify treatment can be performed. Post-treatment sediment verification paired with pre-treatment sample locations can then be collected to assess whether the reaction processes and associated uranium sequestration were induced by the treatment. Post-treatment sediment samples would be analyzed using the same type of sequential extraction, and leaching studies would be conducted on pre-treatment laboratory-treated sediments.

The ammonia treatment process relies on dissolution of minerals due to caustic conditions created by the ammonia, followed by precipitation as the $\mathrm{pH}$ is neutralized. Options for the post-ammonia 
injection period have been investigated to determine whether accelerating the neutralization process through flushing of the treated zone using gas with a high carbon dioxide content is effective. Alternatively, no action can be taken and the treated zone is essentially just exposed to air over time. Figure 4 shows the results of soil-column leaching studies of sediments previously treated with ammonia in the laboratory (Zhong et al. 2014). For one treatment, columns were flushed after ammonia treatment using gas with a high carbon dioxide content. Other treatments were just exposed to air for different periods of time ( 6 weeks [short incubation] or 3 years [long incubation]). The treated sediments were then subjected to leaching by flowing groundwater through the columns and measuring the effluent uranium concentration over time. These results demonstrate that use of carbon dioxide to accelerate pore-water neutralization is detrimental to treatment effectiveness. The results also show that the resistance to leaching is improved with incubation times longer than 6 weeks. While 3 years may not be necessary to reach full treatment effectiveness, it is apparent that incubation time is needed after treatment for neutralization and precipitation reactions to be completed.

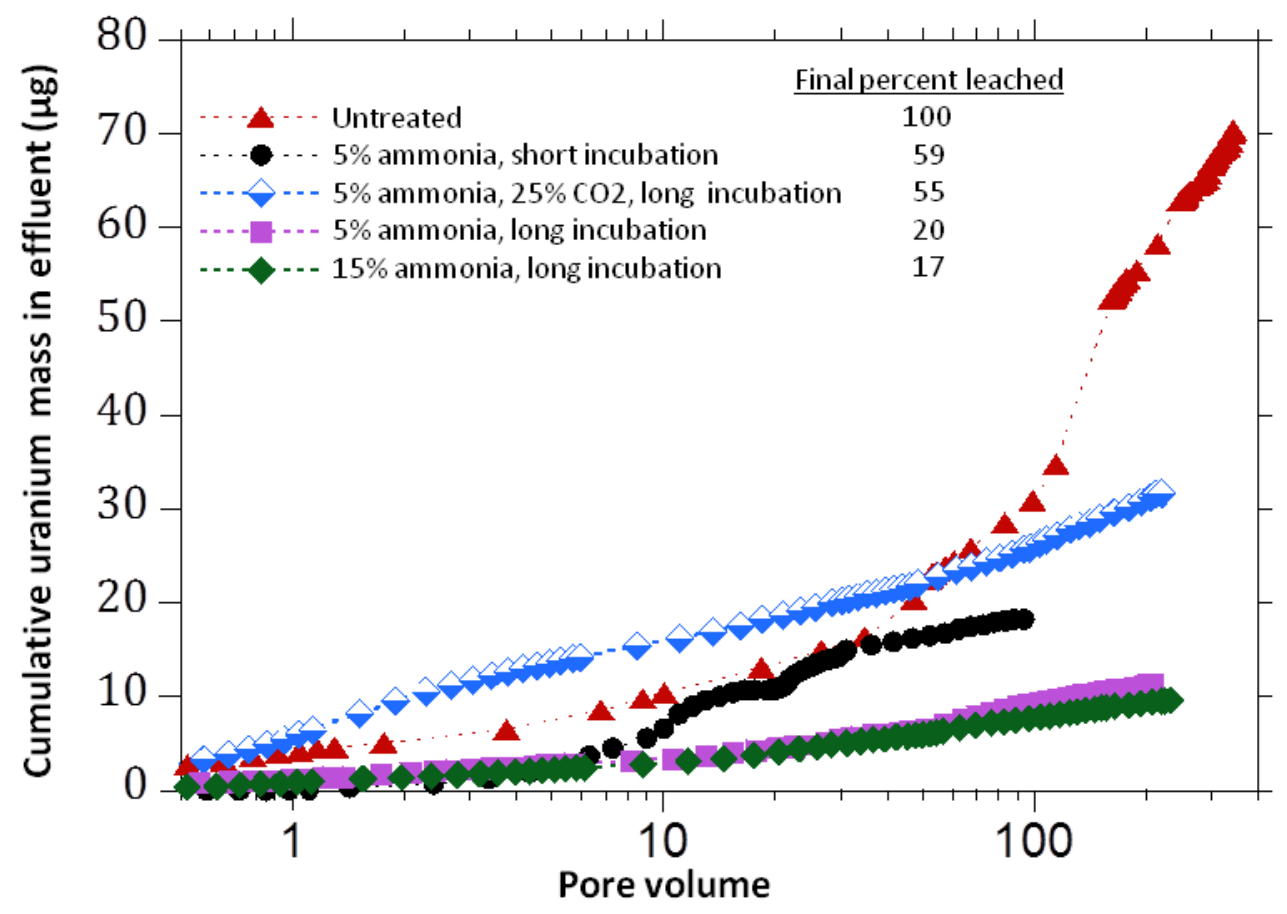

Figure 4. Results of soil-column leaching studies for ammonia-treated sediments and different types of post-treatment exposure gas (air or carbon dioxide) and time 6 weeks (short incubation) to 3 years (long incubation) prior to leaching with groundwater (adapted from Zhong et al. 2014).

\subsection{Ammonia Treatment Design Calculations}

Calculations to support ammonia treatment design can be conducted based on ammonia partitioning behavior and the properties of the subsurface within the treatment zone. For ammonia delivery, basic field design calculations can be made based on the behavior of ammonia with pure water. Under these conditions, ammonia in the gas-phase partitions to the pore water based on Henry's Law (Henry's Law constant, $\mathrm{H}_{\mathrm{NH} 3}$ ) where 


$$
\mathrm{H}_{\mathrm{NH} 3}=\left[\mathrm{NH}_{3}\right]_{\mathrm{gas}} /\left[\mathrm{NH}_{3}\right]_{\mathrm{aq}} \text {. }
$$

The ammonia partitioning into pore water is function of temperature as described in Equation (2),

$$
\left.\mathrm{H}_{\mathrm{NH} 3}\right|_{\mathrm{T}}=1 /\left(\mathrm{e}^{(-9.70+4092 / \mathrm{T})}\right),
$$

where $\mathrm{HNH} 3 \mid \mathrm{T}$ is the Henry's Law partitioning coefficient ( $\mathrm{L} \cdot \mathrm{atm} / \mathrm{mole})$ at a specified temperature and T is temperature in degrees Kelvin (Renard et al. 2004). In the pore water, the ammonia-ammonium system is described by

$$
\left.\mathrm{K}_{\mathrm{NH} 3}\right|_{\mathrm{T}}=\left[\mathrm{NH}_{3}\right]_{\mathrm{aq}}\left[\mathrm{H}^{+}\right] /\left[\mathrm{NH}_{4}^{+}\right]
$$

where the dissociation constant, $\left.\mathrm{K}_{\mathrm{NH} 3}\right|_{\mathrm{T}}$, varies as a function of temperature according to (Clegg and Whitfield 1995),

$$
\ln \left(\left.\mathrm{K}_{\mathrm{NH} 3}\right|_{\mathrm{T}}\right)=\ln \left(\mathrm{K}_{\mathrm{NH} 3 \mid 298.15}\right)+((52252 / \mathrm{R}) \times(1 / 298.15-1 / \mathrm{T})) .
$$

In Equation (4), $\mathrm{R}$ is the universal gas constant $(8.3144 \mathrm{~J} / \mathrm{K} \cdot \mathrm{mole}), \mathrm{T}$ is temperature in degrees Kelvin, and KNH3|298.15 is $5.69 \times 10-10$ mole/L. The amount of ammonia that partitions into the water at equilibrium can be calculated considering that the dissolved ammonia concentration is controlled only by the Henry's Law coefficient and ammonium ion is produced by dissociation until charge balance is obtained with respect to ammonium ion, and ionization of water, such that

$$
\left[\mathrm{NH}_{4}^{+}\right]+\left[\mathrm{H}^{+}\right]=\left[\mathrm{OH}^{-}\right]
$$

The ionization constant for water $\left(\mathrm{pK}_{\mathrm{H} 2 \mathrm{O}}=14.1732\right.$ at $\left.20^{\circ} \mathrm{C}\right)$ can be identified from tabulated values as a function of temperature (http://www.kayelaby.npl.co.uk/). Starting with Equation (3), substituting in $\left[\mathrm{H}^{+}\right]=\mathrm{K}_{\mathrm{H} 2 \mathrm{O}} /\left[\mathrm{OH}^{-}\right]$, and rearranging yields

$$
\mathrm{K}_{\mathrm{H} 2 \mathrm{O}} /\left.\mathrm{K}_{\mathrm{NH} 3}\right|_{\mathrm{T}}=\left[\mathrm{NH}_{4}^{+}\right] \cdot\left[\mathrm{OH}^{-}\right] /\left[\mathrm{NH}_{3}\right]_{\mathrm{aq}},
$$

where $\mathrm{K}_{\mathrm{H} 2 \mathrm{O}}$ is the ionization constant for water. Substituting $\left[\mathrm{H}^{+}\right]=\mathrm{K}_{\mathrm{H} 2 \mathrm{O}} /\left[\mathrm{OH}^{-}\right]$into Equation (5) and then substituting the resulting equation into Equation (6) yields

$$
\mathrm{K}_{\mathrm{H} 2 \mathrm{O}} /\left.\mathrm{K}_{\mathrm{NH} 3}\right|_{\mathrm{T}}=\left(\left[\mathrm{OH}^{-}\right]^{2}-\mathrm{K}_{\mathrm{w}}\right) /\left[\mathrm{NH}_{3}\right]_{\mathrm{aq}},
$$

which can be used to solve for $\left[\mathrm{OH}^{-}\right]$with knowledge of the coefficient values and the computed $\left[\mathrm{NH}_{3}\right]_{\mathrm{aq}}$ from Equation (1) using the input $\left[\mathrm{NH}_{3}\right]_{\text {gas }}$ tracer concentration. Once $\left[\mathrm{OH}^{-}\right]$has been determined, $\left[\mathrm{NH}_{4}{ }^{+}\right]$ can be calculated from Equation (6) and the $\mathrm{pH}$ can be calculated from the ionization equation for water, $\left[\mathrm{H}^{+}\right]=\mathrm{K}_{\mathrm{H} 2 \mathrm{O}} /\left[\mathrm{OH}^{-}\right]$, using the appropriate ionization constant as described above. This approach provides a means to calculate a theoretical total amount of ammonia and ammonium in solution for input ammonia gas concentration. Because of the geochemical reactions that cause speciation of ammonia within the aqueous phase, the movement of ammonia vapor through the partially water-saturated porous medium is a function of a total-species partitioning coefficient $\left(\left.\mathrm{K}_{\mathrm{NH} 3}\right|_{\text {total }}\right)$,

$$
\left.\mathrm{K}_{\mathrm{NH} 3}\right|_{\text {total }}=\mathrm{NH}_{3(\mathrm{~g})} /\left(\left[\mathrm{NH}_{3}\right]+\left[\mathrm{NH}_{4}^{+}\right]\right) \text {. }
$$


The total ammonia required to meet the above calculated equilibrium loading can be calculated based on the amount of water within the targeted treatment zone. The amount of water in this zone can be estimated from the sediment moisture content.

\subsection{Ammonia Transport in the Subsurface}

A series of experiments have been conducted to evaluate ammonia transport in the subsurface with respect to advection and diffusion. A summary of results relevant to evaluating field application of ammonia treatment is presented in the following sections.

\subsection{Ammonia Advection}

Ammonia advection in unsaturated sediments has been studied in 1D soil columns, 2D flow cells (including wedge-shaped flow cells for radial flow), and 3D flow cells (Szecsody et a. 2010a,b, 2013, Zhong et al. 2014). Ammonia partitioning from gas to water phases significantly controls ammonia movement in unsaturated sediment. For ideal equilibrium partitioning, ammonia gas injected into the sediment would partition into the pore water to reach equilibrium concentration before the ammonia gas front (i.e., the front behind which the gas is at the ammonia concentration of the influent) would move downgradient. A sharp front of pore-water ammonia concentration and associated pore-water $\mathrm{pH}$ would also be observed under ideal equilibrium conditions.

Experiments conducted using 6-m-long soil columns at varying gas injection rates all resulted in a $\mathrm{pH}$ profile within the column that was indicative of reaching near-equilibrium $\mathrm{pH}$ up to the ammonia gas front, after which the $\mathrm{pH}$ was sharply lower (Figure 5). Ammonia gas-front retardation relative to the carrier gas flow rate was $202 \pm 31$ in these experiments (Szecsody et al. 2012b). High gas velocities may overcome the partitioning-controlled behavior. For instance, ammonia gas-front retardation relative to the carrier gas flow rate was 363 in a similar column test with a measured ammonia gas-front advection rate of $2200 \mathrm{~cm} / \mathrm{min}$ (Szecsody et al. 2012b). A higher retardation of the ammonia gas front would be observed if equilibrium partitioning were not immediately achieved and a portion of the added ammonia mass moved downgradient in the gas phase without partitioning. In that case, more pore volumes of gas would be required to achieve the equilibrium conditions associated with definition of the ammonia gas front (reaching target $\mathrm{pH}$ conditions). For field implementation, high gas velocity conditions would likely only exist very near an injection well. Because of the strong dependence on equilibrium partitioning, ammonia gas-front advection is faster in low-moisture-content zones compared to higher moisturecontent zones for the same gas velocity (Szecsody et al. 2010b). Ammonia gas-front retardation estimates are very sensitive to the sediment moisture content and porosity. For instance, the computed retardation for sediment moisture content values of 2, 4, and $6 \mathrm{wt} \%$ are 220,510, and 910, respectively, assuming a porosity of $30 \%$. Retardation estimates for a sediment moisture content value of $4 \%$ and 25, 30, and 35\% porosity are 720,510 , and 380, respectively. Thus, an approximate ammonia gas-front retardation factor (ratio of unimpeded movement to retarded movement) can be estimated for field applications. However, variations of the actual retardation factor in the targeted treatment zone should be expected due to variations in moisture content and porosity. 


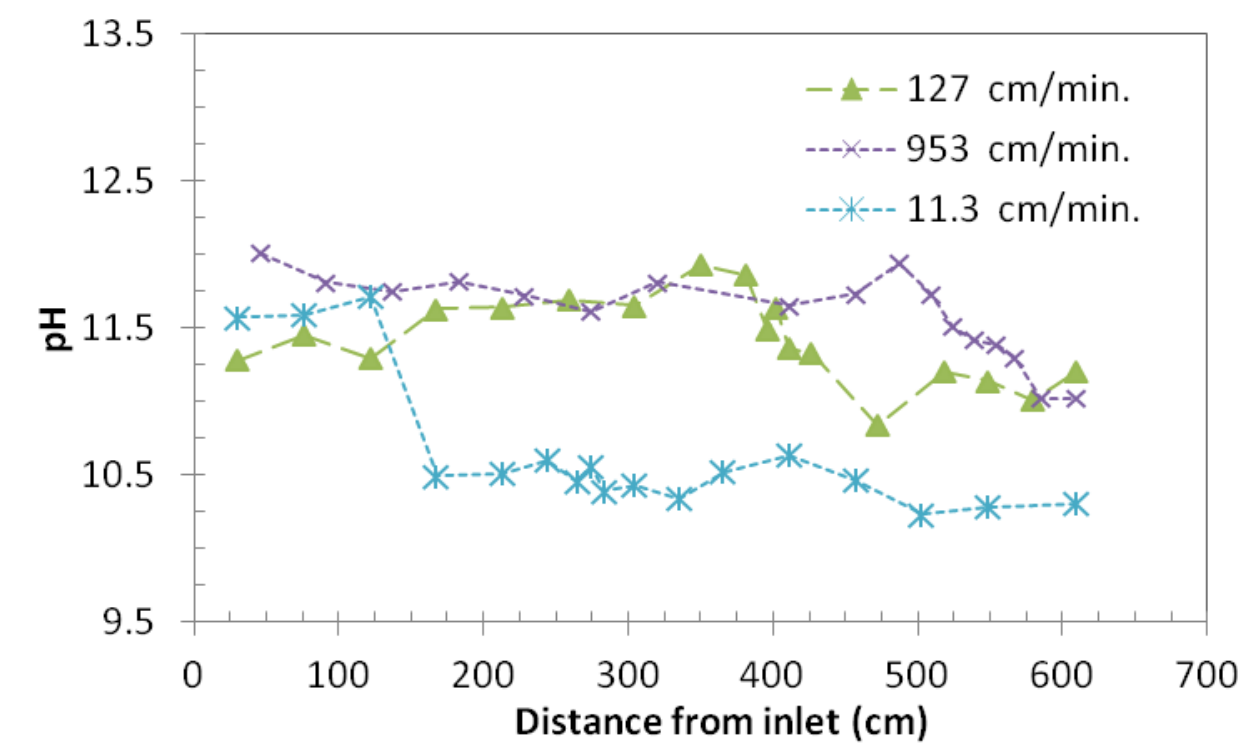

Figure 5. Resulting $\mathrm{pH}$ profile for $\mathrm{NH}_{3}$ gas injection into 610-cm-long (20-ft) columns at different gas flow rates and associated ammonia velocities within the columns. Stable high $\mathrm{pH}$ occurs behind the ammonia gas front, which is shown by a sharp drop in $\mathrm{pH}$. Values shown in the legend are the computed ammonia gas-front advection rate for the experiment (Szecsody et al. 2010b).

\subsection{Ammonia Diffusion}

Advective ammonia distribution largely occurs in the high-permeability and lower moisture-content zones. Thus, ammonia diffusion may be important for evaluating the extent of field-scale treatment that can be expected in low-permeability portions of the subsurface, which would be bypassed by advection. Upgradient of the ammonia injection front, gas concentrations in the primary advective distribution pathways would be expected to be near the injected ammonia gas concentration. Under these conditions, ammonia could diffuse into lower permeability zones. If layers of contrasting permeability and moisture content are present, the relative rates of diffusion and advection are important for evaluating the overall distribution of ammonia in the targeted treatment zone. Ammonia distribution into lower permeability, higher moisture-content zones was qualitatively observed in flow cells with heterogeneous packing (Szecsody et al. 2010b). More quantitative examination of ammonia diffusion was recently evaluated by Zhong et al. (2014), and some of these experiments and results are summarized below.

Zhong et al. (2014) conducted a 2D diffusion study using a 7.62-cm-internal-diameter, 10.16-cm-long soil column with two types of heterogeneous sediment packing (Figure 6). A flow distribution plate was emplaced in each end of the vessel to evenly distribute the gas injection and collect the gas effluent. For the experiments, $26 \mathrm{~L}$ of $5 \%(\mathrm{v} / \mathrm{v})$ ammonia gas was pumped through the soil column at flow rate of 2.5 $\mathrm{mL} / \mathrm{min}$ over a 1-week period. The soil column was then disassembled and sediments at selected distances from the injection end and multiple lateral locations were taken to measure the concentrations of dissolved ammonia in pore water. 

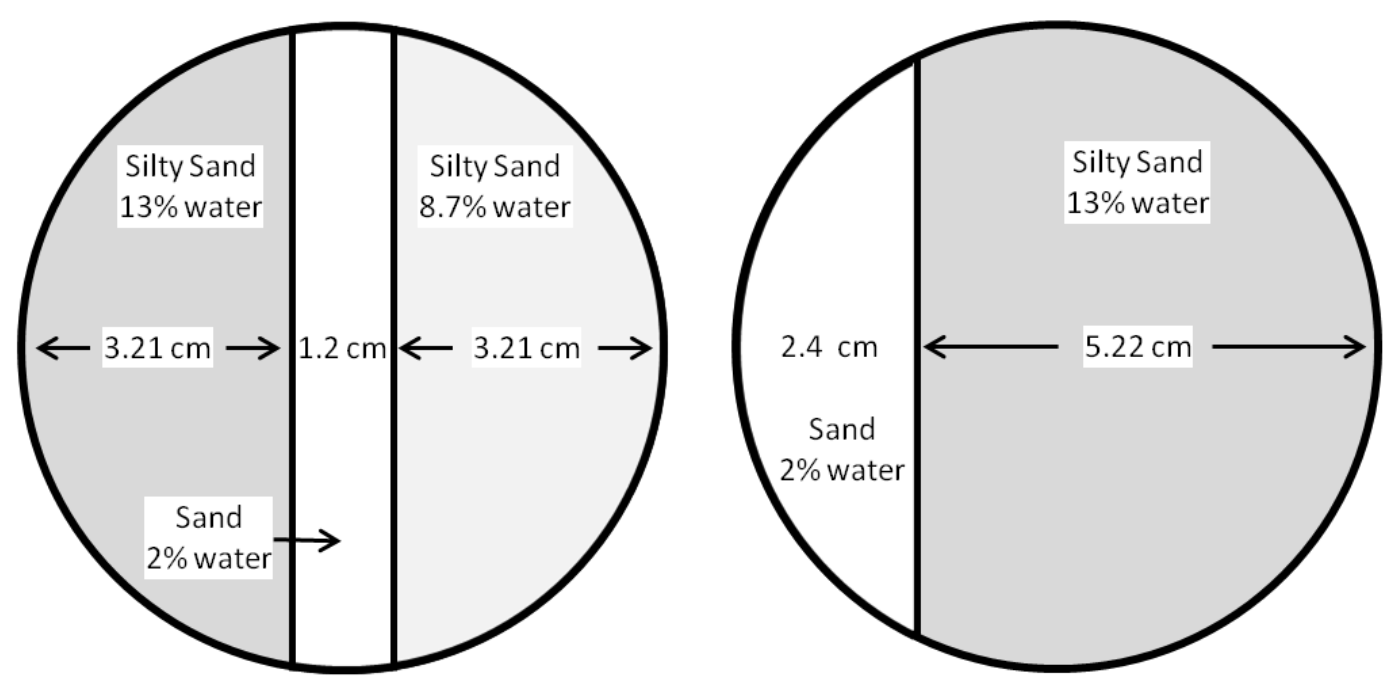

Figure 6. Plan view of heterogeneous sediment packing for 2D diffusion studies with a central highpermeability layer (left) and a side high-permeability layer (right). This packing extended the full length of the soil column.

Although more than enough ammonia to fully saturate the high-permeability, lower moisture-content layer was used in the experiments, ammonia concentrations decrease with distance from the inlet within this high-permeability layer (Figure 7). Lateral ammonia movement into the surrounding lowpermeability, higher moisture-content layers is evident in the observed pattern of ammonia concentrations, with highest concentrations in the layer nearest the inlet and nearest the high-permeability layer. These results demonstrate the slow advection of ammonia due to partitioning in the pore water and the associated significant diffusion into surrounding low-permeability zones. Zhong et al. (2014) used 1D soil columns to quantify diffusion in the same materials and at the same moisture contents as were used for packing the 2D experiments shown in this report. Movement of the $0.1 \mathrm{M}$ ammonia pore-water concentration front (i.e., a front where the pore-water $\mathrm{pH}$ is over 11) due to diffusion from a $5 \%$ ammonia gas boundary condition was observed to be about $0.05,0.03$, and $0.02 \mathrm{~cm} / \mathrm{h}$ for the $2 \%$ moisture content sand, $8.7 \%$ moisture content silty sand, and $13 \%$ moisture content silty sand, respectively (Zhong et al. 2014). These diffusion rates correspond to diffusion distances for a $0.1 \mathrm{M}$ ammonia pore-water concentration of 5 and $3.4 \mathrm{~cm}$ over one week of exposure for the $8.7 \%$ moisture content silty sand, and 13\% moisture content silty sand, respectively. These diffusion distance are consistent with observations of $0.1 \mathrm{M}$ ammonia pore-water concentrations penetrating significantly into the low-permeability portions of the 2D experiments in Figure 7 at the inlet end of the column where a boundary condition high ammonia gas concentration was present for an extended portion of the week-long experiment. As observed, less movement would be expected near the outlet of the 2D experiment where ammonia gas concentrations in the high-permeability layer were lower due to partitioning of ammonia during advection. Due to the configuration of the $2 \mathrm{D}$ experiments, some advection of ammonia into the lowpermeability zones could also have occurred. 

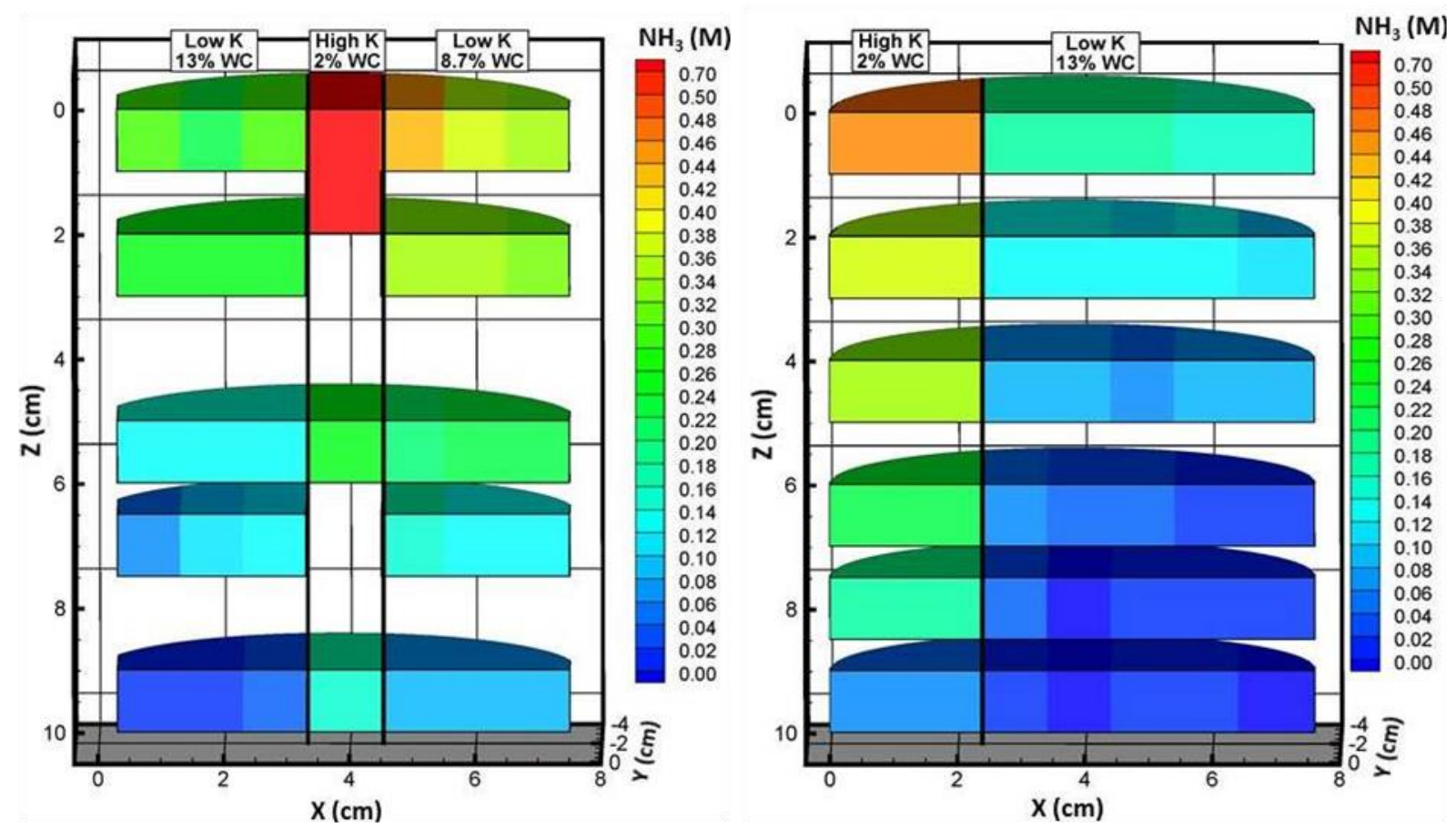

Figure 7. Ammonia pore-water concentration distribution in heterogeneous systems with a central high-permeability layer (left) and a side high-permeability layer (right). Distributions are after one week of ammonia gas injection (Zhong et al. 2014).

\subsection{Ammonia Monitoring}

A series of laboratory experiments have been conducted examining parameters that can be used as part of a monitoring approach. Experimental details are provided by Szecsody et al. (2010a, b, 2013) and Zhong et al. (2014) and summarized here in the context of monitoring the ammonia treatment in the field.

\subsection{Temperature}

Because the ammonia gas-to-liquid partitioning reaction is rapid and exothermic, temperature increases at locations where significant partitioning is occurring. This temperature signal of the ammonia partitioning front is evident in temperature data collected at locations along a $30-\mathrm{ft}$ soil column with injection of $100 \%$ ammonia gas. A temperature increase of as much as a $30^{\circ} \mathrm{C}$ was observed in this experiment with $100 \%$ ammonia gas (Figure 8). For an injection at a 5\% ammonia concentration, the temperature rise is less significant (similar column tests showing on the order of $4^{\circ} \mathrm{C}$ rise), but within a range that can be monitored. Use of temperature monitoring was successfully applied to monitor the progress of desiccation at the field scale based on temperature decreases from evaporation that occurs during desiccation (Truex et al. 2013). 


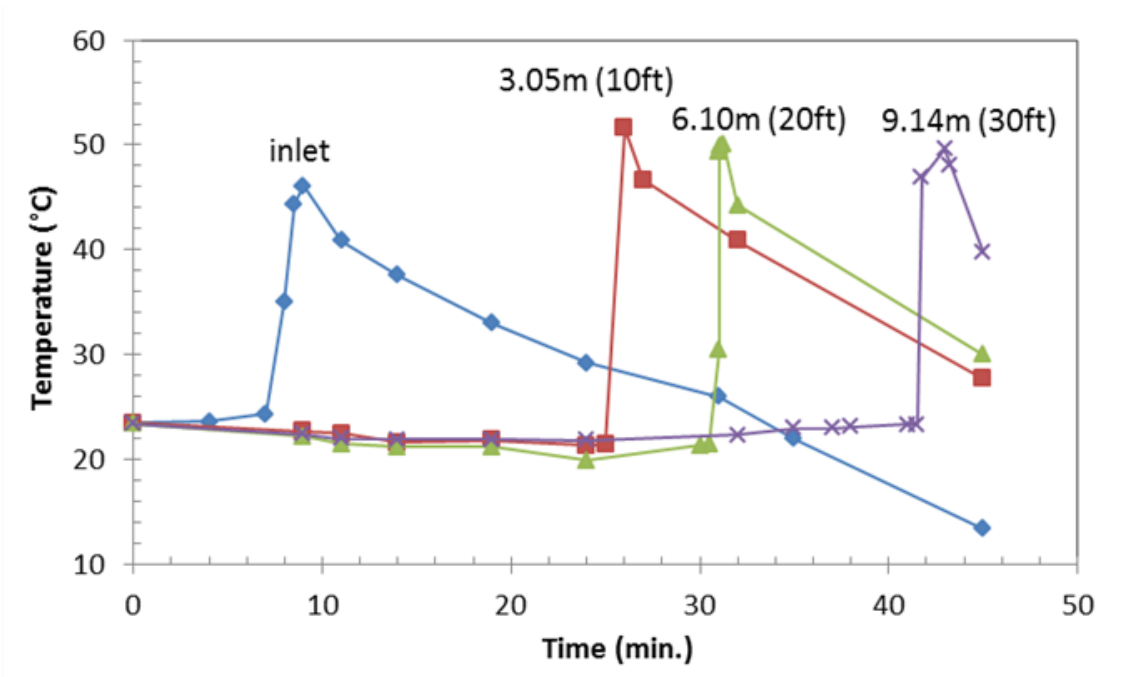

Figure 8. Observed temperature response in a 1D soil column with injection of $100 \%$ ammonia gas. Note the progression of temperature peaks as the ammonia portioning front moved down the column. The inlet temperature drops below the initial temperature because of a small zone of desiccation that developed during the test near the column inlet (Zhong et al. 2014).

\subsection{Bulk and Pore-Water Electrical Conductivity}

In addition to increases in ammonia and ammonium concentrations, ion exchange and mineral dissolution (including silicate dissolution) occur in ammonia-treated sediments because of the caustic $\mathrm{pH}$ induced by ammonia dissociation (Figure 1). The bulk and pore-water electrical conductivity increase as a result of the presence of higher ion concentrations in the pore water. Changes in ion concentrations are greatest in low-moisture-content sediments (Figure 9) for the same imposed ammonia gas concentrations. Over time, ion concentrations decrease as the $\mathrm{pH}$ is buffered and precipitation occurs. Monitoring of specific conductance and ion concentrations has been effective for laboratory experiments as a means to follow the processes of dissolution and precipitation during ammonia treatment (Szecsody et al. 2010a, b, 2013). 


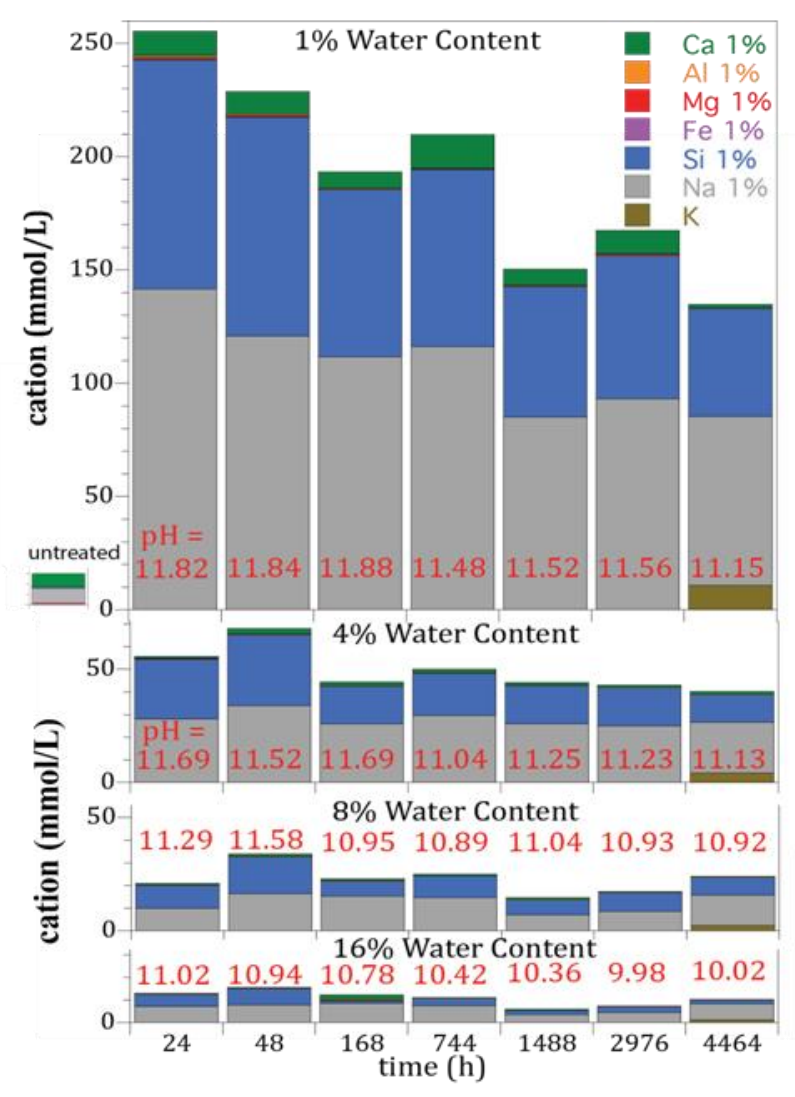

Figure 9. Sediment pore-water cation concentration over time during 10\% ammonia gas treatment (Hanford Formation sediment) for sediment water content values of 1, 4, 8, and $16 \mathrm{wt} \%$. For comparison, pre-treatment ion concentrations for the $1 \%$ water content test are shown to the left of the y axis.

ERT is a means to scale monitoring of electrical conductivity changes to the field. ERT has previously been applied at the field scale in the vadose zone to track the progress of desiccation based on the electrical conductivity changes caused by decreased moisture content (Truex et al. 2013). Laboratory experiments have also demonstrated that ERT can be used to monitor ammonia injection by sensing the electrical conductivity changes associated with ammonia partitioning and induced dissolution and precipitation reactions. The laboratory tests used 2.54-cm-diameter, 30.48-cm-long columns packed with uncontaminated Hanford Formation sediment sieved to $<2 \mathrm{~mm}$ and with a $6.7 \%$ gravimetric water content using a simulated Hanford groundwater chemistry (Szecsody et al. 2010b). The columns used stainlesssteel-mesh current electrodes at each end and two silver/silver chloride potential electrodes on the circumference of the column for ERT measurements. ERT electrodes were spaced $10.16 \mathrm{~cm}$ from each other and $10.16 \mathrm{~cm}$ from each current electrode. Treatments used 5\% ammonia gas injected into each column at $1 \mathrm{~L} / \mathrm{min}$ until ammonia was present in the effluent. Sacrificial columns were used to obtain samples for pore-water chemistry analysis (specific conductivity and inductively coupled plasma-atomic emission spectrometer analysis) at selected times with coincident measurement of the bulk conductivity by ERT.

The bulk conductivity measured by ERT increased by $150 \%$ during ammonia injection. Because of this strong ERT signal with ammonia injection, ERT could be used in the field to track, in three dimensions, the pattern of ammonia gas distribution over time in the subsurface. Figure 10 shows a series 
of graphs for changes in selected pore-water ion concentrations (sodium, aluminum, silica, and calcium), pore-water specific conductance, and bulk conductivity (ERT data) over time after ammonia treatment (i.e., during incubation after ammonia has been delivered to the sediment). In this system, changes in bulk conductivity may be caused by changes in water content and/or changes in fluid specific conductance. The fact that changes in specific conductance and bulk conductivity are inconsistent at time zero suggests there may have been an initial redistribution of pore water during ammonia injection, which is an artifact of the laboratory testing procedure (i.e., this is not expected to occur in the field). For the remainder of the samples, changes in bulk conductivity are consistent with changes in fluid specific conductance, which decreases as ions are removed from pore water during mineral precipitation. The pattern of ERT bulk conductivity response would be useful as a temporal and spatial field indicator of pore-water chemistry and fluid specific conductance associated with precipitation reactions and the related uranium sequestration process. Thus, the ERT data help determine the timing of post-treatment sediment sampling, if needed, to verify treatment effectiveness. Note that temporal and spatial field measurement of pore-water chemistry and specific conductivity through direct sampling would be difficult and expensive in the field. 

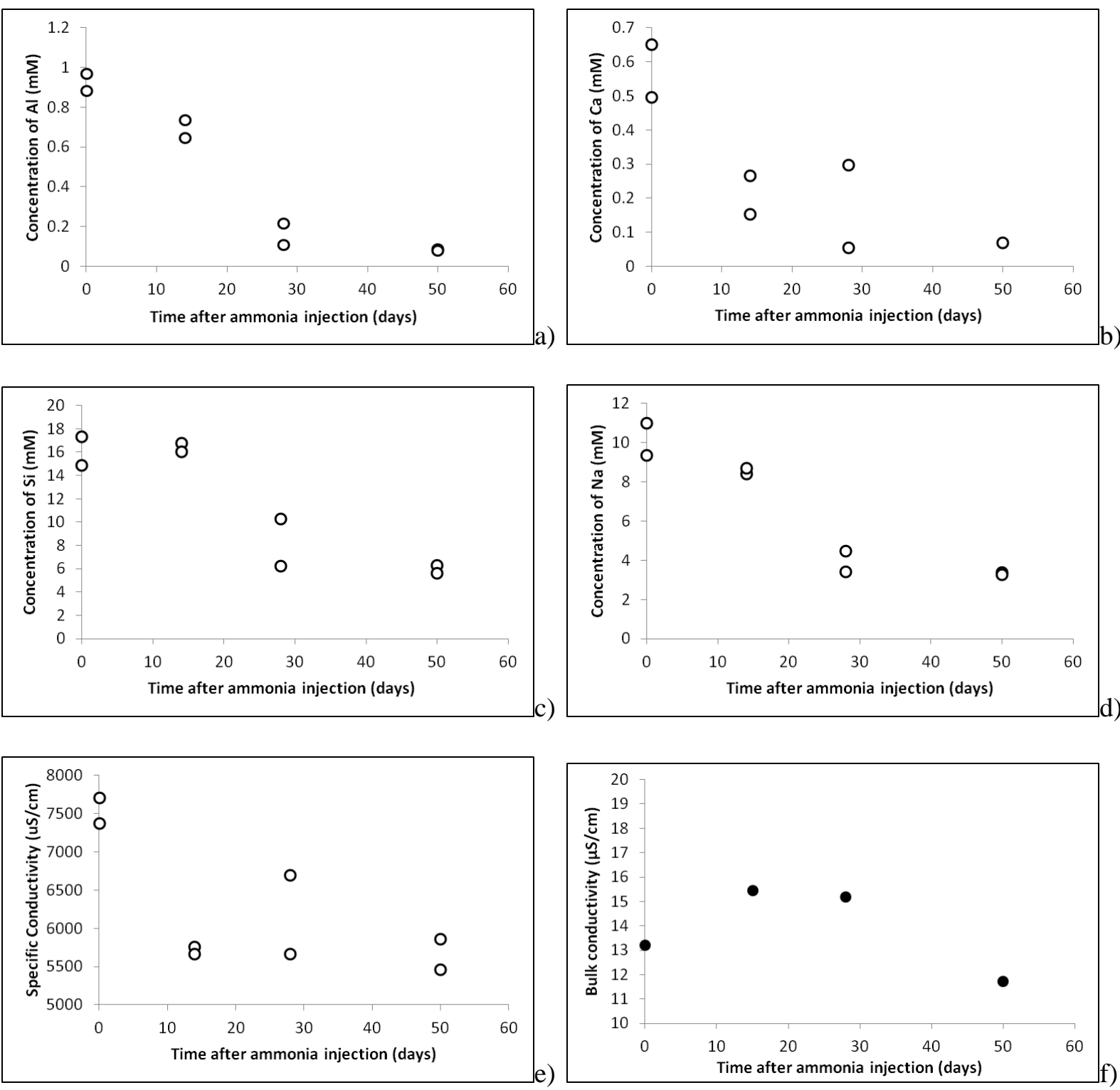

Figure 10. Changes in pore-water ion concentrations (a-d), pore-water specific conductivity (e), and bulk conductivity (f) over time after ammonia treatment. Ion concentrations and specific conductivity are for extracted pore water. Specific conductivity and bulk conductivity plots are the difference between data at each time point and the pre-treatment conductivity measurements of $1200 \mu \mathrm{S} / \mathrm{cm}$ and $29 \mu \mathrm{S} / \mathrm{cm}$, respectively.

\subsection{Sediment Sample Analyses}

Pre- and post-treatment sediment sampling can be useful to integrate with other monitoring strategies as part of demonstrating treatment effectiveness (Section 2.0). Assessment of sediment samples with a sequential extraction technique is useful to evaluate uranium mobility and the impact of ammonia treatment on this mobility (Szecsody et al. 2010a, b, 2013). Table 1 provides a summary of appropriate sequential extraction solutions and their interpretations in terms of uranium mobility in the vadose zone. 
Table 1. Sequential extraction of uranium from sediment samples.

\begin{tabular}{|c|c|c|c|}
\hline Extraction Solution & $\begin{array}{l}\text { Hypothesized Targeted } \\
\text { Sediment Components }\end{array}$ & $\begin{array}{l}\text { Interpreted Uranium Mobility } \\
\text { of Extracted Fraction }\end{array}$ & $\begin{array}{l}\text { Color } \\
\text { Code }\end{array}$ \\
\hline $\begin{array}{l}\text { 1. Aqueous: } \\
\text { uncontaminated } \\
\text { Hanford } \\
\text { groundwater }\end{array}$ & $\begin{array}{l}\text { Uranium in pore water and } \\
\text { a portion of sorbed uranium }\end{array}$ & Mobile phase & \\
\hline $\begin{array}{l}\text { 2. Ion Exch.: } \\
1 \mathrm{M} \mathrm{Mg-nitrate}\end{array}$ & Readily desorbed uranium & $\begin{array}{l}\text { Readily mobile through } \\
\text { equilibrium partitioning }\end{array}$ & \\
\hline $\begin{array}{l}\text { 3. Acetate } \mathrm{pH} 5: 1 \text { hour } \\
\text { in } \mathrm{pH} 5 \text { sodium } \\
\text { acetate solution }\end{array}$ & $\begin{array}{l}\text { Uranium associated with } \\
\text { surface exposed carbonate } \\
\text { precipitates, including } \\
\text { uranium-carbonates, or } \\
\text { other readily dissolved } \\
\text { precipitates }\end{array}$ & $\begin{array}{l}\text { Moderately mobile through } \\
\text { rapid dissolution processes }\end{array}$ & \\
\hline $\begin{array}{l}\text { 4. Acetate pH 2.3: } \\
1 \text { week in } \mathrm{pH} 2.3 \\
\text { acetic acid }\end{array}$ & $\begin{array}{l}\text { Dissolution of most } \\
\text { carbonate compounds, } \\
\text { including uranium- } \\
\text { carbonates, and sodium } \\
\text { boltwoodite }\end{array}$ & $\begin{array}{l}\text { Slow dissolution processes for } \\
\text { uranium release from this } \\
\text { fraction; mobility is low with } \\
\text { respect to impacting } \\
\text { groundwater }\end{array}$ & \\
\hline $\begin{array}{l}\text { 5. } 8 \mathrm{M} \mathrm{HNO}_{3}: 2 \text { hours } \\
\text { in } 8 \mathrm{M} \text { nitric acid at } \\
95^{\circ} \mathrm{C}\end{array}$ & $\begin{array}{l}\text { Considered to represent } \\
\text { total uranium extraction for } \\
\text { this study }\end{array}$ & $\begin{array}{l}\text { Very slow dissolution } \\
\text { processes are associated with } \\
\text { uranium release; functionally } \\
\text { immobile }\end{array}$ & \\
\hline
\end{tabular}

\subsection{Sediment Laboratory Treatment Evaluation}

Pre-and post-treatment sediment samples can be exposed to sequential extraction analysis (Section 5.3) and soil-column leaching studies to evaluate treatment effectiveness. Example soil-column leaching study results for sediments treated with ammonia in the laboratory are shown in Figure 5 (Section 2). This type of assessment can augment the sequential extraction analysis if needed to directly demonstrate that the ammonia treatment has changed the mobility of uranium in the sediment.

\subsection{Processes Affecting Ammonia in the Subsurface}

The long-term fate of ammonia added to the subsurface to induce uranium treatment is (1) volatilization and upward ammonia gas migration in the vadose zone, (2) conversion of ammonia to nitrate in the pore water, and/or (3) $\mathrm{NH}_{4}{ }^{+}$(ammonium) sorption or incorporation into aluminosilicate precipitates. To examine the relative importance of these processes, sediment dosed with $5 \%, 0.5 \%$, or $0.05 \%$ ammonia gas was incubated for varying lengths of time in closed containers so that volatilization of ammonia was not possible (Szecsody et al. 2014). Sacrificial treatments were analyzed for ammonia, nitrate, and nitrite concentrations. In all treatments, no increases in nitrate or nitrite were observed over 3 months of incubation time. Total microbial populations were also measured before ammonia dosing and during incubation. With exposure to a $5 \%$ ammonia gas concentration, representative of the treatment zone concentration, microbial populations starting at about $1 \times 10^{7}$ cells $/ \mathrm{mL}$ declined to non-detectable 
levels. Microbial populations exposed to $0.05 \%$ and $0.5 \%$ ammonia gas concentrations declined by orders of magnitude. The microbial populations exposed to $0.05 \%$ ammonia gas concentrations recovered quickly on exposure to air, whereas populations exposed to higher concentrations showed minimal recovery. These results suggest that the nitrification pathway is insignificant during ammonia injection and the subsequent precipitation phase. Longer duration fate, however, may potentially include nitrification.

\subsection{Quality Assurance}

The Pacific Northwest National Laboratory (PNNL) Quality Assurance (QA) Program is based upon the requirements defined in DOE Order 414.1D, Quality Assurance and 10 CFR 830, Energy/Nuclear Safety Management, Subpart A - Quality Assurance Requirements (a.k.a. the Quality Rule). PNNL has chosen to implement the following consensus standards in a graded approach:

- ASME NQA-1-2000, Quality Assurance Requirements for Nuclear Facility Applications, Part 1, Requirements for Quality Assurance Programs for Nuclear Facilities.

- ASME NQA-1-2000, Part II, Subpart 2.7, Quality Assurance Requirements for Computer Software for Nuclear Facility Applications, including problem reporting and corrective action.

- ASME NQA-1-2000, Part IV, Subpart 4.2, Guidance on Graded Application of Quality Assurance (QA) for Nuclear-Related Research and Development.

The procedures necessary to implement the requirements are documented through PNNL's "How Do I...? (HDI) system, a system for managing the delivery of laboratory-level policies, requirements and procedures.

The DVZ-AFRI Quality Assurance Plan (Meier 2014) is the minimum applicable QA document for all Deep Vadose Zone-Applied Field Research Initiative (DVZ-AFRI) projects. This QA Plan also conforms to the QA requirements of DOE Order 414.1D, Quality Assurance, and 10 CFR 830, Subpart A, Quality Assurance Requirements. The DVZ-AFRI is subject to the Price-Anderson Amendments Act. The implementation of the DVZ-AFRI QA program is graded in accordance with NQA-1-2000, Part IV, Subpart 4.2, Guidance on Graded Application of Quality Assurance (QA) for Nuclear-Related Research and Development.

The work for this report was performed under the technology level of Applied Research. Applied Research consists of research tasks that acquire data and documentation necessary to ensure satisfactory reproducibility of results. The emphasis during this stage of a research task is on achieving adequate documentation and controls necessary to be able to reproduce results. 


\subsection{References}

10 CFR 830. 2001. Code of Federal Regulations, Title 10, Energy, Part 830, "Nuclear Safety Management," Subpart A, "Quality Assurance Requirements." Washington, D.C.

ASME (American Society of Mechanical Engineers). 2001. Quality Assurance Requirements for Nuclear Facility Applications. NQA-1-2000, New York.

Clegg SL and M Whitfield. 1995. A Chemical-Model of Seawater Including Dissolved Ammonia and the Stoichiometric Dissociation-Constant of Ammonia in Estuarine Water and Seawater from -2-DegreesC to 40-Degrees-C. Geochimica Et Cosmochimica Acta 59(12):2403-2421.

Denham ME and BB Looney. 2007. Gas: A Neglected Phase in Remediation of Metals and Radionuclides. Environmental Science and Technology 41(12):4193-4198.

DOE (U.S. Department of Energy). 2011, as amended. Quality Assurance. DOE Order 414.1D, Washington, D.C.

DOE/RL (U.S. Department of Energy/Richland Operations Office). 2008. Deep Vadose Zone Treatability Test Plan for the Hanford Central Plateau. DOE/RL-2007-56, Revision 0, Richland, Washington.

Dresel PE, DM Wellman, KJ Cantrell, and MJ Truex. 2011. "Review: Technical and Policy Challenges in Deep Vadose Zone Remediation of Metals and Radionuclides.” Environmental Science and Technology 45(10):4207-4216.

Meier KM. 2014. Deep Vadose Zone Applied Field Research Initiative Quality Assurance Plan. QADVZ-AFRI-001, Rev. 1, Pacific Northwest National Laboratory, Richland, Washington.

PAAA (Price-Anderson Amendments Act). Energy Policy Act of 2005. Title VI-Nuclear Matters, Subtitle A-Price-Anderson Act Amendments, Section 601 et. seq. Public Law 109-58, as amended. 42 USC 15801 et seq.

Renard JJ, SE Calidonna, and MV Henley. 2004. Fate of ammonia in the atmosphere - a review for applicability to hazardous releases. Journal of Hazardous Materials 108(1-2):29-60.

doi: $10.1016 /$ j.jhazmat.2004.01.015

Szecsody JE, L Zhong, MJ Truex, and N Qafoku. 2014. Remediation of technetium in the vadose zone using reactive gasses $\mathrm{NH}_{3}$ and $\mathrm{H}_{2} \mathrm{~S}$. Submitted to Vadose Zone Journal.

Szecsody JE, MJ Truex, N Qafoku, DM Wellman, T Resch, and L Zhong. 2013. Influence of acidic and alkaline waste solution properties on uranium migration in subsurface sediments. Journal of Contaminant Hydrology 151:155-175. dx.doi.org/10.1016/j.jconhyd.2013.05.009.

Szecsody JE, MJ Truex, L Zhong, TC Johnson, NP Qafoku, MD Williams, JW Greenwood, EL Wallin, JD Bargar, and DK Faurie. 2012. "Geochemical and Geophysical Changes During NH3 Gas Treatment 
of Vadose Zone Sediments for Uranium Remediation.” Vadose Zone Journal 11(4). doi: 10.2136/vzj2011.0158.

Szecsody JE, MJ Truex, L Zhong, NP Qafoku, MD Williams, JP McKinley, CT Resch, JL Phillips, D Faurie, and J Bargar. 2010a. Remediation of Uranium in the Hanford Vadose Zone Using Ammonia Gas: FY10 Laboratory-Scale Experiments. PNNL-20004, Pacific Northwest National Laboratory, Richland, Washington.

Szecsody JE, MJ Truex, L Zhong, MD Williams, and CT Resch. 2010b. Remediation of Uranium in the Hanford Vadose Zone Using Gas-Transported Reactants: Laboratory-Scale Experiments. PNNL-18879, Pacific Northwest National Laboratory, Richland, Washington.

Truex MJ, TC Johnson, CE Strickland, JE Peterson, and SS Hubbard. 2013. "Monitoring Vadose Zone Desiccation with Geophysical Methods.” Vadose Zone Journal 12(2). doi:10.2136/vzj2012.0147.

Zhong L, NP Qafoku, JE Szecsody, PE Dresel, and ZF Zhang. 2009. Foam Delivery of Calcium Polysulfide to Vadose Zone for Cr(VI) Immobilization - Laboratory Evaluation. Vadose Zone Journal 8(4). doi: 10.2136/vzj2008.0124.

Zhong L, JE Szecsody, MJ Truex, and MD Williams. 2014. "Ammonia Gas Transport and Reactions in Unsaturated Sediments: Implications for Use as an Amendment for Immobilize Inorganic Contaminants." Submitted to Journal of Hazardous Materials. 
PNNL-23699

RPT-DVZ-AFRI-025

\section{Distribution}

No. of

Copies

2 U.S. Department of Energy Richland Operations Office

Hard Copy:

Briant Charboneau

John Morse
No. of

Copies

$\begin{array}{cc}\text { pdfs } & \begin{array}{l}\text { Pacific Northwest National } \\ \text { Laboratory } \\ \text { MJ Truex }\end{array} \\ \text { JE Szecsody } & \text { (PDF) } \\ \text { L Zhong } & \text { (PDF) } \\ \text { JN Thomle } & \text { (PDF) } \\ \text { TC Johnson } & \text { (PDF) } \\ & \text { (PDF) }\end{array}$

Distr.1 




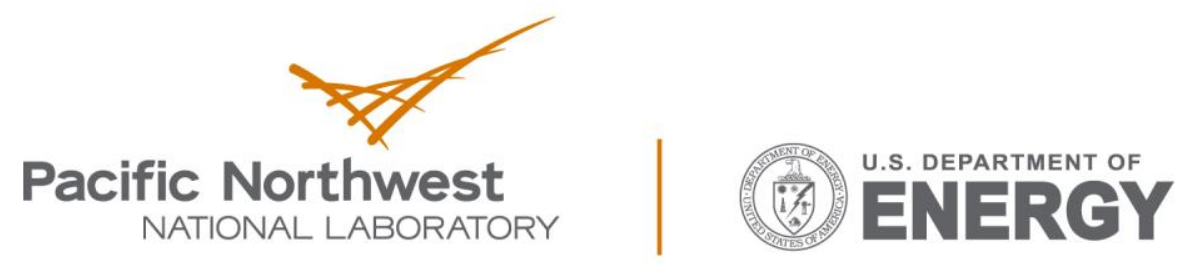

Proudly Operated by Battelle Since 1965

902 Battelle Boulevard

P.O. Box 999

Richland, WA 99352

1-888-375-PNNL (7665)

www.pnnl.gov 